\title{
Groundwater Potentiality Prediction Using AHP- MCDA and GBT Model in a Typical Basement Complex, Nigeria: Insights From Remote Sensing and Geophysical Datasets
}

\section{Balogun Olabode Olumide}

Federal University of Technology Akure

Akintorinwa Olaoluwa James

Federal University of Technology Akure

Mogaji Kehinde Anthony ( $\sim$ kamogaji@futa.edu.ng )

Federal University of Technology Akure

\section{Research Article}

Keywords: GBT, AHP, Machine learning, GIS, Groundwater potentiality, geologic features

Posted Date: January 12th, 2022

DOI: https://doi.org/10.21203/rs.3.rs-1167034/v1

License: (c) (1) This work is licensed under a Creative Commons Attribution 4.0 International License.

Read Full License 
Groundwater potentiality prediction using AHP-MCDA and GBT model in a typical basement complex, Nigeria: insights from remote sensing and geophysical datasets

Balogun Olabode Olumide, Akintorinwa Olaoluwa James and Mogaji Kehinde Anthony

Balogun Olabode Olumide: olumidebalogun@gmail.com

Akintorinwa Olaoluwa James : ojakntorinwa@futa.edu.ng

Mogaji Kehinde Anthony: kamogaji@futa.edu.ng

Department of Applied Geophysics, Federal University of Technology, Akure, Nigeria.

Affiliations : Department of Applied Geophysics, Federal University of

Technology, P.M.B. 704, Akure, Nigeria

Corresponding Author Email: kamogaji@futa.edu.ng 


\begin{abstract}
Delineation of geologic features that are capable of hosting water in economic quantity in the Basement Complex has been a major concern because they are usually localized due to restricted fractured and weathered rock. To effectively evaluate the groundwater potentiality prediction index (GPPI) accuracy of an area, solely depends on the groundwater potentiality predictors (GPPs) considered and the statistical model used in analyzing the data. Therefore, the acquired remotely sensed and geophysical depth sounding database processed using autopartial curve matching software and computer aided iteration to determine was analyzed using the conventional Analytical Hierarchy Process (AHP) model and the machine learning Gradient Boosting Tree (GBT) data driven model. Such a data driven model (GBT) is efficient in solving complex and cognitive problems in high uncertainty and complex environments. Twelve (12) groundwater potentiality predictors (GPPs) namely: Digital Elevation Model (DEM), Slope (S), Drainage Density (Dd), Land Use (Lu), Aquifer Resistivity ( $\rho$ a), Aquifer Thickness (h), Overburden Thickness (b), Aquifer Hydraulic Conductivity (k), Aquifer Transmissivity (Tr), Aquifer Storativity (St), Aquifer Diffusivity (D), Aquifer Reflection Coefficient (Rc). The efficacy of GBT model was applied using the Salford Predictive Modeler 8.0 software. The data were partitioned into training and test dataset in ratio 90:10 using k-10 cross validation techniques. Their prediction importance was determined and the groundwater potentiality prediction index calculated and processed in the ArcGIS environment to produce the groundwater potential prediction index (GPPI) map of the investigated area. The investigated area was classed into three (3) zonations of low, moderate and high groundwater potential with about $56 \%$ classed within the low groundwater potential zone. Fifteen (15) water column measurement from wells was used to validate the developed model by calculating the predictive correlation accuracy (PCA) using the spearman's correlation analysis. The AHP-GPPI and GBT-GPPI model gave a correlation of $\left(\mathrm{r}_{\mathrm{s}}=0.66 ; \mathrm{p}=\right.$ $.007)$ and $\left(r_{s}=0.74 ; p=.002\right)$ respectively. In conclusion, the model has proven that the drop in aquifer resistivity doesn't necessitate the presence of groundwater but rather several parameter should be integrated together to better understand the true nature of the aquifer.
\end{abstract}

Keywords: GBT, AHP, Machine learning, GIS, Groundwater potentiality, geologic features. 


\section{Introduction}

According to Boretti and Rosa (2019), the global demand for water, presently about 4,600 $\mathrm{km}^{3}$ volume of water per year, will increase by $20 \%$ to $30 \%$ by 2050 as a result of an expected increase in global population between 9.4 to 10.2 billion people, an increment of $22 \%$ to $32 \%$ by 2050 . This demand has led to an intense pressure on geophysicist and some inexperienced workers have maximize that as an opportunity to exploit money from individuals who want their demands met at all cost, therefore leading to an increase in the numbers of abortive or unproductive well, loss of money and time and has brought a bad reputation on geophysics as a discipline. Delineation of geologic features that are capable of hosting water in economic quantity in the Basement Complex has been a major concern because they are usually localize due to restricted fractured and weathered rock (Fashae et al. 2014: Akintorinwa, 2015: Akanbi, 2018). Over the years, several efforts has been made to narrow the search of the groundwater system for maximum exploitation. Millions of publications have been written which has in turn made search for groundwater easier. The groundwater modeling has been playing significant role in sustainable water resource management. To be specific, groundwater potentiality modeling has been effective in diverse ways (Mogaji, 2016: Akinlalu, 2017: Sunmin et al., 2019). Akintorinwa et al., (2020) have proved that these models can be used to analyze geophysical, hydrogeological and Geographic Information System (GIS) data which provides adequate information which are very useful reconnaissance tool in delineating groundwater potential zone. Modeling is an attempt to replicate the behavior of natural groundwater or hydrologic system by defining the essential features of the system using some controlled physical or mathematical manner. Modeling plays an extremely important role in the management of hydrologic and groundwater system (Rawal et al., 2016). Moreover, In recent 
years, the use of the Geographic Information System (GIS) has grown rapidly in groundwater management and research. GIS is now widely used to create digital geographic databases, to manipulate and prepare data as input for various model parameters, and to display model output. The GIS tool has been used in recent years in solving groundwater related problem and it has proven to be very effective (Adiat et al., 2013, Mogaji and Lim, 2016; Rawal et al., 2016; Akinwumiju and Olorunfemi, 2018; Akintorinwa and Okoro, 2019).

To effectively analyze and improve the groundwater potential predictive capacity of an area with high accuracy, this solely depends on groundwater potentiality predictors considered and statistical model used in analyzing the data. Researchers such as Mogaji and Lim (2016); Akintorinwa et al. (2020) concluded that the groundwater availability within an area strongly depends on certain groundwater potentiality predictors (GPPs) such as overburden thickness, aquifer thickness, overburden resistivity, aquifer resistivity, aquifer hydraulic conductivity and aquifer transmissivity. According to Lohman (1972), Singh (2005), Pradhan et al. (2013) and Mogaji and Lim (2017), the following established aquifer hydraulic properties (aquifer transmissivity, aquifer hydraulic conductivity, aquifer storativity, and aquifer hydraulic diffusivity) can be determined from geoelectric derived parameters as a second order parameter to better characterize the groundwater potentiality of the area. On the other hand, several statistical model have been put in place to critically analyze and weigh groundwater potentiality predictors, recently adopted machine learning softwares are not exempted. Gradient Boosting Tree (GBT) has been applied by data scientist in several fields as data mining models for big data analyses, trends and pattern recognition. The GBT model has unique attributes including highly efficient in solving complex and cognitive problems. Such a data-driven analysis (GBT) model is necessary in areas of high uncertainty and complexity (Basement Complex) terrain in estimating groundwater potential. 
Adopting this model into the geophysical sphere, will of no doubt help to predict appropriate locations for groundwater exploitation (Sunmin et al. 2019).

This paper conceptualized providing valuable information on hydrogeological conditions that is favorable for groundwater accumulation in a typical Basement Complex using sophisticated GBT data mining model to integrate remotely sensed data and geophysical data derived Groundwater Potentiality Predictors (GPPs) parameters for higher accurate mapping and reliable prediction of groundwater potential zones.

\section{Materials and methods}

\subsection{The geographic and hydrologic description of the investigated area}

Figure 1, shows the basemap of the investigated area. The area is an inland town that is located within Abeokuta, which is one of the most prominent urban settlements in the South-western Nigeria. The area falls between the Universal Traverse Mercatum (UTM) Zone 31, Minna datum coordinate of Latitudes 788400 to $789400 \mathrm{mN}$ and Longitudes 536800 to $538200 \mathrm{mE}$ with the entire area spanning about 480 square kilometers. The area has elevation ranging from 67 to $98 \mathrm{~m}$ above the sea level, annual rainfall ranges from 848.9 to $1777.3 \mathrm{~mm}$ and an annual potential evapotranspiration of about $188 \mathrm{~mm}$ (Akanni 1992). The earmarked area falls within the Basement Complex of the geological setting of South-Western Nigerian, underlain mainly by crystalline basement rocks described as older granites (Rahaman, 1988)(Fig. 2). The older granites around Abeokuta are of late Precambrian to early Palaeozoic in age and are magmatic in the origin (Jones and Hockey, 1964). The gneiss-migmatite complex is widespread in Abeokuta where the study area is located, comprising of undifferentiated granite, charnokitic rocks, medium to coarse granite and Migmatite gneiss rocks (Rahaman, 1976). The occurrence of groundwater is controlled by factors such as geology, structures and climate (Ademilua, 1997; Ozdemir 2011; Mogaji et al. 
2021). The geology and structures determine the nature of the aquifer while the climate determines the amount and rate of recharge of the aquifer (Lewis, 1987). Nature of geologic formations hosting groundwater are usually of more concern to the geophysicist than the groundwater itself (Jayeoba and Oladunjoye, 2013: Mogaji et al., 2021). These geologic formations could be of varying degrees of fracture, faults and incipient joints caused by multiple tectonic events on hard rock when the rock strength is exceeded by stress (Hencher et al., 2011). Thereby causing the rock to lose cohesion along its weakest plane and enhancing the permeability of that formation. These permeable material contains networks of cracks that are both numerous enough to allow free movement of water. Hydrogeology of weathered-fractured aquifers is highly heterogeneous due to complexity in geological, structural and geomorphological features (Akanbi, 2017). Aquifer hosting groundwater are majorly of two types: weathered basement aquifer and fracture basement aquifer (Umar and Igwe 2019; Shisaye et al. 2019). These aquifer types greatly contribute to the development of shallow and deep groundwater sources, respectively. Aquifer with high appreciable amount of thickness can largely enhance the groundwater potential (Akintorinwa $e t$ al., 2020). The highest groundwater yield in basement terrains is found in areas where thick overburden overlies fractured zones (Olorunfemi and Fasuyi, 1993).

The area is easily accessible through major roads, minor roads and footpath. It is well developed with appreciable settlements such as banks, police station, hospitals, INEC office, markets, Opic, eateries, luxury hotels, schools among others.

\subsection{Database preparation using RS, GIS and Geophysics}

In an attempt to achieve the required aim, two basic approaches were adopted, which include remote sensing approach and geophysical approach. This section describes the preparation and 
acquisition of the data (Table 2) into the geographical information system for preparing spatial databases. Fig.4 describe the methodological flow adopted in this study.

a. Remotely sensed data: A Geographic Information System (GIS) is described as framework for gathering, managing and analyzing data. Four (4) remotely sensed data within the investigated area were extracted and inputted into the Geographic Information System Software (ArcGIS 10.6) which Z values were then plotted as spatial data against latitude and longitude coordinate using inverse distance weighting (IDW) method. The data were presented in form of maps to visualize and analyse the spatial distribution across the investigated area.

b. Geophysical data: The geoelectrical method data aquisiition as shown in Fig. 3. Sixty-two (62) depth sounding data were occupied using Schlumberger configuration with $(A B / 2)$ ranging from $1-120 \mathrm{~m}$. The sounding station were established randomly by maintaining an inter-station spacing of $100 \mathrm{~m}$ interval as much as possible. The apparent resistivity $\left(\rho_{\mathrm{a}}\right)$ values were obtained as the product of the resistance $(\mathrm{R})$ read from the resistivity meter and its corresponding geometric factor (G) calculated (Zohdy et al., 1974). The VES were quantitatively interpreted using autopartial curve match software (Ogunbo, 2019). The software follows the principle of the mannual partial curve matching technique by plotting the apparent resistivity $\left(\rho_{\mathrm{a}}\right)$ on the ordinate and half current electrode spacing $(\mathrm{AB} / 2)$ on the abscissa using logarithmic scale. The resulting curves were sectionalized into branches based on the gradient change in the curve that relate to resistivity contrast between layers. Then the preliminary interpreted geoelectrical parameters (layer resistivities and thicknesses) obtained was used as start-up model for a computer aided iteration (VanderVelpen, 2004) to determine the geo-electrical parameters as seen in (Table 1). The final 
VES interpretation results was then used to determine the second order hydrogeologic predictors relevant to groundwater potentiality using the established aquifer hydrogeologic properties equation by Lohman (1972), Singh(2005), Pradhan et al.,(2013) and Mogaji and $\operatorname{Lim}(2017)$.

c. Water column data: Inventory of fifteen (15) hand-dug wells were taken across the study area. The water column was obtained by subtracting the static water level measurement (m) from the well depth (m) (Akintorinwa et al., 2020).

\subsection{The MCDA-AHP model's theory utilized}

The concept of Analytical Hierarchy Process (AHP) techniques was developed by Thomas Saaty in the 1970 as an appropriate approach to quantify weights for multi-criteria decision analysis (MCDA). Expert's opinions from publication (Akintorinwa et al 2020) were sought on the relative importance of the aforementioned GPP's variables regarding the area underlain aquifer unit formation groundwater potentiality degree. The expert weights were provided to different GPPs considered and further calibrated using Saaty's scale ranging from 0 - 9 (Saaty and Vargas 1991). The maximum weight were assigned to the themes of highest aquifer potentiality and the minimum weights to the lowest potential themes. The pair-wise comparison matrix of the GPPs as shown in Table 3 was developed using the result from Saaty scale output. Solving Table 3 matrix, the normalized weights $(\mathrm{Nw})$ were finally checkmated for consistency assignment for each of the GPPs indices.

The AHP techniques normaizes the assigned weight using the eigen vector techniques, which reduces the bias involved in the expert opinions assigned weights. The normalized weights were checked for consistency by computing consistency ratio (CR) for the generalized themes. Saaty (1980) suggested that the assigned weights are consistent and accepted only when the consistency 
ratio remains within $10 \%$, otherwise, the weights should be re-considered to remove the inconsistency. The computed consistency ratio was calculated to be $3 \%$, hence, the results of the normalized weights was consisitent and was considered for the groundwater Potentiality mapping. The computation of the consistency ratio involves three steps: (1) principal eigenevalue lamda max was computed by eigenvector techniques as reported in (Mogaji et al., 2021, Akintorinwa et al .2020), (2) Consistency index (CI) was calculated using Eq 1.

$$
C I=\frac{\lambda \max -n}{n-1}
$$

Where lamda max is the average value of the consistency vector, and $\mathrm{n}$ is the number of factors and (3) consistency ratio computed using Eq. (2)

$$
C R=\frac{C I}{R I}
$$

Where RI is the random index for twelve (12) criteria obtained from the standard table provided in Saaty (1980) given as 1.48 .

$$
A H P-G G P I=\sum N w \times R
$$

The groundwater potential index obtained using the analytical hierarchy process (AHP) data mining techniques was calculated using Eq. (3) as the product of the normalized weight as seen in column 8 of Table 4 and rating of each category as seen in column 7 of Table 4 . The summation of these products was used to produce the AHP-GPPI as seen in Table 5 of column 14.

\subsection{The GBT model theory and it algorithm}

Boosting is an ensemble learning methodology that creates strong learners through the use of multiple weak learners and is a technique for both regression and classification problems. It helps 
combine predictions from a set of weak learners, and eventually, their average predictions from strong learners. The GBT model was applied using the Salford Predictive modeler 8.0 software to integrate several groundwater potential conditioning factors (GPPs') themes for groundwater potential mapping in this study (Table 2). The data was partitioned into training and testing data set in ratio 90:10 using the k-10 cross validation techniques. In other words, the data were partitioned into 10 bins which were randomly selected as shown in Table 6. Nine (9) bins were used as training data set while the remaining one (1) bin was used to test the trained data. This was repeatedly iterated for ' $n$ ' times and the average of the accuracy was calculated. Since the target data was a continuous variable, the regression supervised model technique was adopted. The residual for the subsequent boosting step is calculated through sum squared error. Finally, for the GBT model in Salford Predictive Modeler 8.0, the learning rate was set to 0.01. The tree complexity was set to 5 and the bag fraction was set to 0.5 as reported in sunmi et al. 2020. Given the training set, GBT calculates the prediction probability using Equation (4) according to Friedman (1999).

$$
\text { input data: }\left\{\left\langle x^{(i)}, y^{(i)}\right\rangle\right\}_{i=1}^{n}
$$

Where $x^{(i)}$ are the twelve (12) groundwater potential predictors (GPPs)such as slope, resistivity, drainage etc. while $y^{(i)}$ is the target data, in this case total traverse resistance. The target data is usually a factor used for the computation process which gives the algorithm a clue that best describes the groundwater potential condition of that area. The most appropriate target data in this case should have been borehole yield or static water level measurement. However, due to the unavailability of this data, the nearest most suitable factor used in describing groundwater potentiality (transverse resistance) was used instead.

$$
\text { initialise model: } h o(x)=\operatorname{argmin} \sum_{i=1}^{n} L\left(y^{(i)}, \hat{y}\right)
$$


The root node $h_{0}(x)$ is computed by calculating the average of the target data $(\hat{y})$, which is the traverse resistance.

for $=1$ to $T$; where $\mathrm{T}$ is the total number of trees iterations

compute pseudo residual $r_{i, t}=-\left[\frac{\partial L\left(y^{(i)}, h\left(x^{(i)}\right)\right)}{\partial h\left(x^{(i)}\right)}\right]_{\mathrm{h}(\mathrm{x})=h_{t-1}(x)}$

We build the next tree based on the errors of the previous tree by computing the pseudo residual given as $r_{i, j}$. The pseudo residual was calculated by subtracting the actual data from the predicted data.

Fit tree to $r_{i, j}$ values, and create terminal nodes $R_{j, t}$ for $\mathrm{j}=1, \ldots, J_{t}$

$$
\text { for } \mathrm{j}=1, \ldots, J_{t} ; \quad \hat{\mathrm{y}}_{j, t}=\operatorname{argmin} \sum_{X^{(i)} \in R_{i, j}} L\left(y^{(i)}, h_{t-1}\left(x^{(i)}\right)+\hat{\mathrm{y}}\right)(7)
$$

Equation7 above was used to compute the loss by adding the actual data (in this case the prediction of the previous rounds) and the newly predicted round

The estimation of the groundwater potential index in relation to Gradient Boosting Tree (GBTGPPI) model is constructed by combining all the trees

$$
\text { Update: } \quad h_{t}(x)=h_{t-1}(x)+\alpha \sum_{j=1}^{j} \hat{\mathrm{y}}_{i, t}\left(x \in R_{j, t}\right)
$$

GBT-GPPI expressed in Eq.8 is given such that a new decision tree $h_{\mathrm{m}}(\mathrm{x})$ is created by combining the previous model (iteration from initial trees) plus new prediction step weighted by the learning rate added to the ensemble so that the composition maximizes the likelihood. This process is the summation of all the previously iterated model in other to reduce the errors and produce a more appropriate prediction. 


\subsection{The predictive model map validation scheme}

In a view to establish the predictive accuracy of a Gradient Boosting Tree model map for the decision-making process in groundwater studies, performance evaluation is highly essential (Chang-Jo and Andrea, 2003). The model performance was evaluated by calculating the area under curve (AUC) in the graph plot of the receiver operating characteristics (ROC) curve. The partitioned test data was used to validate the trained dataset. According to Zhu et al.(2010), AUC value within $0.9-1.0$ is classified as excellent, values within $0.8-0.9$ are classified as good and values within $0.7-0.8$ are classified as poor. The ROC includes a success rate curve and prediction rate curve.

\subsubsection{The water column validation (WC-VLD)}

The primary objective of the validation process applied is to ascertain the results from AHPMCDA model and GBT prediction model, thereby comparing the results of evidential field data gotten from hand dug wells with theoretical data gotten from the model. In other words, water column of wells in the area was used to validate the groundwater potential map developed from the AHP and GBT model. Majority of the people in the investigated area depends majorly on community boreholes, some few hand-dug wells and water supplied from state water corporation body. For this reason only few hand-dug wells were documented for the validation process. In addition, for the quantitative modeling analysis of these engaged approaches output, a statistical correlation computation algorithm as used in the studies of (Sedgwick, 2019) explored using the IBM SPSS 21 software.

Correlation measures the extent of relationship existing between two or more variables by determining their strength and directions (Kothari, 2004). The nonparametric spearman's correlation $\left(\mathrm{r}_{\mathrm{s}}\right)$ analysis was adopted for this study as it assumption necessitate that 
i. The variables are all ordinal variables in our used case that is the variables are classified in a certain order such as low, moderate and high groundwater potential;

ii. The data is non normally distributed as reported in section 3.5.

iii. There exist a monotonic relationship between these variable.

Evidence proving the existence of this assumption was further reported in section 3.5 of this report. Correlation can occur in any of the three ways, -1.00 is a perfect negative correlation, +1.00 is a perfect positive correlation and 0.00 means there is no relationship between variables being tested (Kothari, 2004).

Correlation analysis of the groundwater potentiality prediction index (GPPI) of both predictive models from equation 9 was presented in details in column 7,8 and 9 as shown in Table 7 .

$$
\begin{aligned}
& r_{s}=1-\frac{6 \sum d_{i}^{2}}{n\left(n^{2}-1\right)} \\
& \mathrm{r}_{\mathrm{s}}=\text { Spearman's rank correlation coefficient } \\
& \mathrm{d}_{\mathrm{i}}=\text { difference between the two ranks of each observation } \\
& \mathrm{n}=\text { number of observations }
\end{aligned}
$$

\subsection{Geoelectrical predictors modeling approach (GPMA)}

The GPMA was achieved by incorporating the measured geoelectrical data at sixty two (62) locations into a mathematical equation. These data were processed and interpreted for imaging subsurface lithology (see Fig. 3). Eight (8) geoelectrical parameter were considered as predictors 
for this study. The aquifer resistivity ( $\rho$ a), aquifer thickness (h) and overburden thickness (b) as seen in Table 1 were obtained from the autopartial curve match software coded by Ogunbo, (2019) and iterated with 1D forward modeling (Vander-Valpen, 2004) for the delineated subsurface lithologies. The resistivity and thickness of aquiferous layer have been successful evaluated for groundwater potential. On the other hand, relatively high overburden thickness enhances the productivity of boreholes in some parts of the basement complex of southwestern Nigeria (Olorunfemi and Olorunniwo 1987: Mogaji 2016a). These parameters were further reprocessed using the established groundwater flow equations reported in the studies of Mogaji and Lim, (2020) and Akintorinwa et al. (2020) to determine the second order hydrogeologic factors relevant to groundwater prediction modeling. The aquifer hydraulic conductivity $(\mathrm{k})$ was estimated using equation (10) as given by Singh (2005). The hydraulic conductivity has been established as one of the major drivers of groundwater discharge in an area for it largely determined the variability of groundwater potential from place to place Okugbue and Omonona (2013).

The aquifer transmissivity which defines the measure of the quantity of water that the aquifer can transmit horizontally was estimated using the equation (11) as modified by Pradhan et al.(2013), aquifer storativity was established using equation (12) Lohman (1972), aquifer diffusivity was estimated based on the principles established by Hiscock (2005) equation (13) and reflection coefficient (RC) was estimated in equation (14) stated by Olayinka (1996). Olayinka (1996), observed that an area of lower reflection coefficient value $(<0.8)$ exhibits weathered or fractured basement rock thus, favors a high groundwater potential. The total traverse resistance $(\mathrm{T})$ has been proven by many researchers to define the largest area of groundwater potential, therefore the total traverse resistance will be considered as the target variable for this model (Toto et al., 2008; 
Akintorinwa et al.,2020). The total traverse resistance (T) of each VES was determined by using equation (15).

$$
k=0.0538 e^{0.0071 \rho}
$$

Where,

$$
\begin{aligned}
& k=\text { Hydraulic Conductivity (m/day) } \\
& \rho=\text { Aquifer Resistivity. } \\
& \mathbf{T}=\mathrm{k} \times \mathrm{h}
\end{aligned}
$$

Where:

$$
\begin{aligned}
& \mathrm{T}=\text { Aquifer Transmissivity }\left(\mathrm{m}^{2} \mathrm{day}^{-1}\right) \\
& \mathrm{k}=\text { Hydraulic Conductivity of the Aquifer }\left(\mathrm{mday}^{-1}\right) \\
& \mathrm{h}=\text { Aquifer Thickness }(\mathrm{m}) . \\
& \mathrm{S}_{\mathrm{t}}=3 \times 10^{-6} \mathrm{~h}
\end{aligned}
$$

Where:

$$
\begin{aligned}
& \mathrm{S}_{\mathrm{t}}=\text { Aquifer Storativity } \\
& \mathrm{h}=\text { Thickness }(\mathrm{m}) \\
& D=\frac{T r}{S t}
\end{aligned}
$$

Where:

$$
\text { D = Hydraulic Diffusivity Parameter }
$$




$$
\begin{aligned}
& \operatorname{Tr}=\text { Aquifer Transmissivity }\left(\mathrm{m}^{2} \mathrm{day}^{-1}\right) \\
& \mathrm{St}=\text { Aquifer Storativity }(\mathrm{m}) \\
& R c=\frac{\rho 2-\rho 1}{\rho 2+\rho 1}
\end{aligned}
$$

Where:

$$
\begin{aligned}
& \rho_{2}=\text { Resistivity of the Layer below the Aquifer } \\
& \rho_{1}=\text { Resistivity of the Aquifer. } \\
& T=\sum_{i=1}^{n} h i \rho i=h i \rho i+h 2 \rho 2+\cdots+h n \rho n
\end{aligned}
$$

Where:

$$
\begin{aligned}
& \mathrm{h}=\text { Layer Thickness } \\
& \rho=\text { Layer Resistivity }
\end{aligned}
$$

\subsection{Results and discussion}

\subsubsection{Digital Elevation Model}

During precipitation, meteoric water from the atmosphere flows in form of run-off from higher elevation to areas of lower elevation. Digital Elevation Model (Dem) map reveals that the study area is dominated by hilly formation at the southeastern part of the study area which is greater than $98 \mathrm{~m}$ (Fig. 5). The model map zoned the investigated area into three digital elevation model classes: $<91 \mathrm{~m}, 92-97 \mathrm{~m}$ and $>98 \mathrm{~m}$. It is evident from Fig. 5a that the digital elevation model is relatively high ( > $98 \mathrm{~m}$ ) in southwestern part of the area with a coverage extent of $211.2 \mathrm{~km}^{2}(44 \%)$ while the least significant digital elevation model $(<77 \mathrm{~m})$ occurs in the northern part of the area with 
a coverage extent of $115.2 \mathrm{~km}^{2}(24 \%)$. Areas of low elevation greatly influence groundwater potentiality, because the surface water is given enough time to infiltrate into the subsurface, thereby enhancing the groundwater rechargeability (Das et al., 2017).

\subsubsection{Slope}

The slope map was generated from the triangulated irregular network (TIN) that was obtained from the elevation surface values through interpolation using the processed digital elevation model (DEM) Landsat Image. The slope tool in ArcGIS environment calculates the maximum rate of change in value of a cell to it's neighbours which identifies the steepest downhill descent from the cell. The slope $(\mathrm{S})$ in the study area ranges from $0-26^{\circ}$. The slope for the investigated area shown in Fig. $5 \mathrm{~b}$ is classified into three classes (Table 3) ranging from $0-4^{\circ}$ (gentle slope), $4.01-6^{\circ}$ (moderate slope) and slope greater than $6.01^{\circ}$ (steep slope). The relatively high or steep slope of the investigated area with area extent of $\left(240 \mathrm{~km}^{2}\right)$ implies a rapid run-off, therefore the surface water precipitating from the atmosphere is always on motion (Das, 2018) and is not given enough time to settle and infiltrate the subsurface to enhance the aquifer. Areas with gentle slope are relatively flat with area extent of $129.6 \mathrm{~km}^{2}$. These are favorable condition of the occurrence of groundwater potential because they influence high infiltration rate and therefore allowing more percolation of surface water into the subsurface as reported in Raviraj et al. (2017).

\subsubsection{Drainage Density}

Drainage density can be calculated in the ArcMap software using the line density tool. The drainage pattern of the study area was obtained from the Digital Elevation Model (DEM) by filling the sinks in Dem. Areas with high drainage density is one of the predictors that causes rapid runoff which indicate that the chances of the water infiltating the subsurface to enhance the groundwater recharge is low. The drainage density map of the investigated area as shown in Fig. 
$5 c$, reveals that the drainage network of the study area are evenly distributed. The low drainage density of class of $6.12-66.5 \mathrm{~km} / \mathrm{km}^{2}$ has a coverage extent of $168 \mathrm{~km}^{2}(35 \%)$. The investigated area is dominated with low drainage density and an average drainage density of $90 \mathrm{~km} / \mathrm{km}^{2}$.

\subsubsection{Land Use}

Land use is used to describe the physical material, which may include vegetation (natural or planted) or man-made constructions (buildings, etc.) which occur on the surface of the earth. Land use may include grass, asphalt, trees, bare ground, water, etc. The land use data was extracted from ALOS PALSAR database at Alaska satellite facility. The area comprises of built-up areas, vegetation and outcrop or bare land (Fig. 5d). Shaban et al. (2006) mentioned that vegetation absorb water which prevent water loss thereby influencing groundwater recharge. The study area is dominated by built-up areas and are made up of entirely non porous surface (roads and building) which reduces the surface water infiltration into the subsurface, thereby reducing the groundwater recharge. More than $84 \%$ of the investigated area with area extent of $403 \mathrm{~km}^{2}$ is made up of builtup areas (Table 3). This also implies that the area is well-developed

\subsubsection{Curve Types}

The sounding curves vary from 3 to 5 layers. The curve types observed in the area are 3-layer Atype (10\%); 3-layer H-type (71\%); 4-layer HA-type (5\%); 4-layer KH-type (5\%); 5-layer HKHtype (10\%). The H-curve type is the predominant curve type in the area (Fig.5e) with area extent of $340.8 \mathrm{~km}^{2}$. The intermediate layer in the H-curve type of the investigated area is characterized by low resistivity value comprising of clayey formation saturated with water and this layer is usually very porous with low specific yield and permeability. In other words, majority of the groundwater reservoir has an high storing capacity but poor transmitting power, thereby leading to low groundwater potentiality. 


\subsubsection{Aquifer Resistivity}

Majority of the aquifer resistivity ( $\rho$ ) values falls within the range of 6 - $37 \mathrm{Ohm}-\mathrm{m}$ with area extent of $172 \mathrm{Km}^{2}$ (Fig.5f) which are suspected to be highly decomposed and disintegrated fragment of rocks that has weathered into clay. Materials like this usually don't have capacity for high groundwater potential because they usually store and hardly transmit groundwater. The findings is in line with the study of (Bayowa, 2014) proven that the drop in aquifer resisititvy doesn't ascertain the presence of groundwater. These geologic formations are generally referred to as an aquitard. Based on the resistivity values, the delineated geologic layer(s) hosting the groundwater are suspected to be clay, fractured and weathered rock formation.

\subsubsection{Aquifer Thickness}

The aquifer thickness (h) can greatly influence the groundwater potentiality of an area, basically the thicker the aquifer unit of an area, the higher the groundwater potential. The Southeastern part of the area is dominated by low aquifer thickness ranging between $0.91-10 \mathrm{~m}$ (Fig. $5 \mathrm{~g}$ ), but majority of the aquifer exceed a thickness of $11 \mathrm{~m}$. Publications of groundwater potentiality within similar geology Akintorinwa et al (2020) reported that thicknesses within this range are considerable as good groundwater potential for domestic use.

\subsubsection{Overburden Thickness}

The overburden thickness (b) value in the study area generally ranges from $0.3-13.7 \mathrm{~m}$ (Fig. h) with more than $63 \%$ of its value falling within the classes of low overburden thickness $(0.3-1.98$ m). The overburden thickness is relatively thin in most parts of the study area. Areas of relatively thick overburden are prospective areas of high groundwater potential. This is because the borehole case may be screened during installation which will further allow seepage and infiltration of water 
from the surrounding geologic material to positively influence groundwater potential. However, this should not be done in areas prone to pollution.

\subsubsection{Aquifer Hydraulic Conductivity}

The aquifer hydraulic conductivity (k) map of the study area (Fig.i), reveals that the hydraulic conductivity decreases radially from the $\mathrm{SW}-\mathrm{NE}$ direction. Based on aquifer classification using hydraulic conductivity values, aquifer accounts for about $22 \%$ of the delineated geologic formation with area extent of $105.6 \mathrm{~km}^{2}$. This reveals there are two major geologic formation hosting the groundwater in the investigated area, which are aquifer and aquitard. One key difference between the two formations is that an aquifer stores and transmit water while an aquitard stores but poorly transmit groundwater, a typical example is sandy clay. Hydraulic conductivity values between the range of $10^{-4}$ and $10^{-1}$ indicating that the layer is an aquitard while values between $10^{-1}-10^{3}$ indicate that the layer is an aquifer (Freeze and Cherry, 1972).

\subsubsection{Aquifer Transmissivity}

Clusters of high aquifer transmissivity (Tr) value was observed at the central part of the study area. Areas of high transmissivity, reveals high groundwater potential. Fig.j reveal that the area is dominated by low aquifer transmissivity ranging between $0.1-0.9 \mathrm{~m}^{2} /$ day covering an area extent of $254.4 \mathrm{~km}^{2}$. Hence, large portion of the study area may be said to be of low groundwater potential.

\subsubsection{Aquifer Storativity}

The eastern part of the study area is dominated by low storativity (St) ranging between 0.000018 -0.00011 with percentage frequency of $44 \%$ and an area extent of $211.2 \mathrm{~km}^{2}$ while the western part of the map is dominated by high storativity with percentage frequency of $32 \%$ and an area 
extent of $153.6 \mathrm{~km}^{2}$ (Fig.j). Although the aquifer storativity (St) value is almost evenly distributed across the study area but area the can be generally classified to be of low aquifer storativity which signifies a low groundwater potential.

\subsubsection{Aquifer Diffusivity}

The aquifer diffusivity has a direct relationship with the groundwater potential (Mogaji and Lim 2016). The northeastern and southwestern part of the investigated area is dominated by high aquifer diffusivity greater $8961 \mathrm{~m}^{2} /$ day (Fig.k). The study area is predominantly of low diffusivity value; therefore, the study area can be rated to be of low groundwater potential.

\subsubsection{Aquifer Reflection Coefficient}

Area of low reflection coefficient value lesser than 0.8 are suspected to be weathered or fractured Basement rock thus, favors a high groundwater potential Olayinka (1996). The low aquifer reflection value observed at the Central and Western parts of the study area (Fig.l) is indicating a high degree of weathering and it correlates with areas of high hydraulic conductivity values. More than $91 \%$ of the aquifer reflection coefficient $(\mathrm{Rc})$ value exceed the cut off value specified by

Olayinka (1996), hence indicating that the layer is less porous and has low potential for groundwater accumulation. On the other hand, the more porous layers with low reflection coefficient values are suspected to have undergone some sort of deformation. Although the causes and source of this deformation is not within the scope of this study, however, the influence of aquifer reflection coefficient $(\mathrm{Rc})$ on groundwater potential cannot be overlooked. These areas of intense deformation are very porous and exhibits potential for groundwater accumulation, therefore suspected as promising target for high groundwater potential. 


\subsection{AHP-MCDA model application results in groundwater potentiality}

The integral focus of this study is to accurately map the status of the aquifer units underlying the regions subsurface for effective groundwater resources management using the knowledge driven AHP-data mining techniques.

The AHP-GPPI algorithm is expressed in Eq. 3. GPPI algorithm application's was developed by considering the weightage contributions of the hydrogeological signifcance of each of the GPPs' themes, applied as a product of the normalized weight $(\mathrm{Nw})$ and Rating $(\mathrm{R})$ as reported in section 2.3.

The results of the AHP-GPPI presented in Table 4 of column 8 show that aquifer transmissivity (Tr) was recorded to have the highest normalized weight of 0.256 while digital elevation model (Dem) and slope (S) have the lowest normalized weight of 0.016 .

\subsection{GBT model application results in groundwater potentiality}

The groundwater potentiality modeling of delineated aquifer units in the field of groundwater hydrology/hydrogeology has been boosted via applying gradient boosting tree data mining techniques. The Gradient Boosting Tree (GBT) model was used to evaluate several GPPs, which were then ranked according to their prediction importance as presented in Fig.6. The aquifer transmissivity (Tr) has the highest prediction importance value of 1.0, overburden thickness (b) equals 0.50, aquifer resistivity ( $\mathrm{AQR}$ ) equals 0.38 , aquifer thickness (h) equals 0.25 , aquifer reflection coefficient (Rc) equals 0.23 , aquifer diffusivity (D) equals 0.19 , drainage density (DD) equals 0.096 , land use ( $\mathrm{Lu}$ ) equals 0.014 , hydraulic conductivity (k) equals 0.013 , digital elevation model (Dem) equals 0.012, slope (S) 0.01 and storativity (St) has a prediction importance of 0.01 (Fig.6). 
As seen in Fig.7 the success rate curve gives an AUC value 0.95 (95\%) revealing how well the model was able to train with the dataset, while the prediction rate curve gives an AUC value of $0.92(92 \%)$ which reveals if truly the machine has properly understood and recognize patterns in the data; in other words, we are testing what the machine has learnt.

\subsection{Groundwater prediction potential index (GPPI) Map}

Results of the AHP-GPPI data mining techniques revealed three zonation classes of low, moderate and high groundwater potential. Results as seen in Figure 8 shows that classes of low groundwater potential falls within the range of $1.07-1.64$ and has an area coverage of $187.2 \mathrm{~km}^{2}(39 \%)$, moderate within the range of $1.65-2.22$ has an area coverage of $153.6 \mathrm{~km}^{2}(32 \%)$ and high groundwater potential within the range of $2.23-2.80$ has an area coverage of $139.2 \mathrm{~km}^{2}(29 \%)$.

On the other hand, the GBT-GPPI model as shown in Fig.9, reveals that classes of low groundwater potential falls within the range of $294.72-873.58$ with an area coverage of $220.8 \mathrm{~km}^{2}(46 \%)$, moderate groundwater potential falls within the class range of $873.59-1345.8$ with an area percentage coverage of $48 \mathrm{~km}^{2}(10 \%)$ and high groundwater potential falls within the class range of 1345.9 - 2238 with an area coverage of $211.2 \mathrm{~km}^{2}(44 \%)$. The northern and western part of the map was dominated by area with high groundwater as shown in (Fig.8). More than $56 \%$ of the area falls within the low groundwater potential.

\subsection{Validation of the groundwater potential prediction (GPPI) Model}

Exploring data insight from the data mining models results using the water column validation (WC-VLD) approaches has been reported in section 2.4.1 of this study. All assumption being met (Fig.10), the groundwater potentiality prediction index (GPPI) of the AHP and GBT model presented in column 4 of Table 6 were classified into three categorical variables. This variable was 
re-interpreted for numerical values digitization and grouped into low, moderate and high water column measurement. The categorized data was recoded on the IBM SPSS users interface as low equals 1 , moderate equals 2 and high equals 3.

The above discussed qualitative analysis of WC-VLD were quantitatively evaluated by substituting the corresponding water column measurement remarks into the statistical correlation algorithm expressed in Eq. 6. The deviation of the model prediction from the WC measurement were recorded in column 9 of Table 8, and it's remark clearly stated.

The low water column measurement $<0.511 \mathrm{~m}$ with area extent $192 \mathrm{~km}^{2}(40 \%)$, moderate of 0.512 $-0.873 \mathrm{~m}$ with area extent $129 \mathrm{~km}^{2}(27 \%)$ and high water column measurement of $0.874-1.45 \mathrm{~m}$ with area extent of $158.4 \mathrm{~km}^{2}(33 \%)$ as seen in Figure 11. The AHP-GPPI model shows a strong positive relationship of $\left(\mathrm{r}_{\mathrm{s}}=0.662\right)$ with WC-VLD and statistically significant value of $(\mathrm{p}=.007)$. This implies that AHP model result and water column validation are both moving in a positive direction with $66 \%$ correlation. The significant value of p equals .007 indicate that there $0.7 \%$ likelihood the results occurred by chance therefore there is $99.3 \%$ confidence the results is accurate. Likewise, the GBT-GPPI model shows a strong positive relationship of $\left(\mathrm{r}_{\mathrm{s}}=0.738\right)$ and ( $\mathrm{p}$ value $=0.002)$ with $\mathrm{WC}-\mathrm{VLD}$. Unlike the AHP model, the GBT model shows a much more stronger association of $74 \%$ and $99.8 \%$ chances this association or relationship is statistically significant as reported in Table 9. 


\subsection{Conclusion}

The development of a predictive modeling data mining technique in the field of groundwater hydrology/hydrogeology is germane for onward decision-making process as it enhances precise mapping and delineating of hidden structures capable of serving as groundwater reservoirs (aquifer unit) on a regional scale. This research conceptualized the development of Groundwater Potentiality Prediction Index (GPPI) data mining techniques for effective planning and management of groundwater resources. To achieve this task, the derived Groundwater potential predictors (GPPs) obtainable from geophysical (subsurface data sources) and remote sensing (Surface data sources) were subjected to a renowned analytical hierarchical process-multi-criteria decision analysis (AHP-MCDA) techniques and a congnitive data mining tool gradient boosting tree (GBT) model in the company of GIS tool.

Values within the range of $77-115 \mathrm{~m}, 0-14.7$ degree, $6.1-281 \mathrm{~km} / \mathrm{km}^{2}$ and $0-147$ for surface hydrological parametes (SHPs) such as digital elevation model (Dem), Slope (S), Drainage density (Dd) and Land use (Lu) respectively are derived from the aforementioned surface data sources. The other GPPs including aquifer resisititvy $(\rho)$, aquifer thickness (h), overburden thickness (b), aquifer hydraulic conductivity (k), aquifer transmissivity (Tr), aquifer storativity (St), aquifer diffusivity (D) and aquifer reflection coefficient (Rc). i.e. subsurface geoelectrical parameters (SGPs) were estimated from the processed and interpreted geophysical 1Ddepth sounding data using the groundwater flow equation.

The applied AHP data mining technique established the weightage contributors of GPPs with aquifer transmissivity predictors ranked highest weightage of 0.256 and digital elevation model and slope predictors ranked lowest weightage of 0.016. Applying the determined GPPs' based Gradient Boosting Tree algorithm, the GBT-GPPI data mining model was developed with 
transmissivity having the highest prediction importance of 1 and slope having the lowest prediction importance of 0.01 .

Results from the hydraulic conductivity value classification and the reflection coefficient revealed that the groundwater is housed by two major geologic layers (aquifer and aquitard). Validation results of $66 \%$ and $74 \%$ were established respectively for AHP and GBT model of the adopted water column validation schemes on the GPPI data mining techniques. Consequently, the aquifer potentiality Prediction model map developed be used to guide the decision of groundwater resources planners and policy makers in the study and in any other area with similar geology

In conclusion, the model has proven that the sudden drop in aquifer resistivity doesn't necessitate the presence of groundwater but rather several parameters should be integrated together to better understand the true nature of the aquifer.

Availability of data and materials (data transparency): Yes, the evidence of data availability statement is present within the text of the manuscript.

\section{Ethical Statement}

The authors declare that no funds, grants or other support were received during the preparation of this research and no conflict of interest

Authors 'contributions -

All authors contributed to the study conception and design Methodology: [Akintorinwa

Olaoluwa James \& Mogaji Kehinde Anthony], ...; Formal analysis and investigation: ...; Writing - original draft preparation: [Balogun Olabode Olumide, ...]; Writing - review and editing: [Mogaji Kehinde Anthony] and all authors commented on previous versions of the manuscript. All authors read and approved the final manuscript 



\section{References}

Ademilua OL (1997) A Geoelectric and Geologic Evaluation of Groundwater potential of Ekiti and Ondo States, Southwestern, Nigeria. Unpublished M.Sc.Thesis, Dept. of Geology, ObafemiAwolowo University, Ile-Ife, Nigeria. pp. 1- 67.

Adiat KAN, Nawawi MNM, Abdullah K (2013) Application of Multi-Criteria Decision Analysis to Geoelectric and Geologic Parameters for Spatial Prediction of Groundwater Resources Potential and Aquifer Evaluation Pure Appl. Geophys. 170, 453-471DOI 10.1007/s00024 012- 0501-9.

Akanbi OA (2017) Hydrogeologic characterization of crystalline basement aquifers of part of Ibarapa area, southwestern Nigeria. Ph.D. thesis. Department of Geology, University of Ibadan

Akanbi OA (2018) Hydrogeological Characterisation and Prospect of Basement Aquifers of IbarapaRegion, Southwestern Nigeria. Appl Water Sci8, $89 \quad$ (2018). https://doi.org/10.1007/s13201018-0731-9

Akanni CO1(992) Aspects of Climate: Ogun State in Maps. Ed Onokomaiya et al. Rex Charles Publication, Ibadan. Pp 21-22.

Akinlalu AA, Mogaji KA, Adebodun TS (2021) Assessment of aquifer vulnerability using a developed "GODL" method (modified GOD model) in a schist belt environ Southwestern Nigeria. Environ Monit Assess 193:19

Akinlalu AA, Adegbuyiro A, Adiat KAN, Akeredolu BE, Lateef WY (2017)Application of multicriteria decision analysis in prediction of groundwater resources potential: A case of 
Oke-Ana, Ilesa Area Southwestern, Nigeria. NRIAG Journal of Astronomy and Geophysics, 6(1), 184-200. https://doi.org/10.1016/j.nrjag.2017.03.001

Akintorinwa OJ, Atitebi MO, Akinlalu AA (2020) Hydrogeophysical and aquifer vulnerability zonation of a typical basement complex terrain: A case study of Odode Idanre southwestern Nigeria. https://doi.org/10.1016/j.heliyon.2020.e0 4549.

Akintorinwa OJ, Okoro OV (2019) Combine electrical resistivity method and multicriteria. GIS-based modeling for landfill site selection in the Southwestern Nigeria. Environmental Earth Sciences 78(5). DOI: 10.1007/s12665-019-8153-z

Akintorinwa (2015) Groundwater Potential Assessment of Iwaro-Oka, SW Nigeria Using Geoelectric Parameters. Current Journal of Applied Science and Technology. 6(4):364377. DOI:10.9734/BJAST/2015/14584

Akinwunmi and Olorunfemi (2018). Modeling Groundwater Flow System of a Drainage Basin in the Basement Complex Environment of Southwestern Nigeria. Proceedings of the International Cartographic Association. Https://Doi.Org/10.5194/ica-proc-1-2-2017.

Bayowa OG, Olorunfemi OM, Akinluyi OF, Ademilua OL (2014) A preliminary approach to the groundwater potential appraisal of Ekiti State, southwestern $\quad$ Nigeria. Int $\quad$ J Sci Technol 4(3):48-58

Boretti A, Rosa L (2019) Reassessing the Projections of the World Water Development Report npj Clean Water 2, 15 (2019). https://doi.org/10.1038/s41545-019-0039-9

Chang-Jo FC, Andrea GF (2003) Validation of spatial prediction models for landslide hazard mapping. J Hydrol 30(3):451-472

Das S (2018) Geographic information system and AHP-based flood hazard zonation of vaitarnabasin, Maharashtra, india. Arab J Geosci 11(19):576 
Fashae OA, Tijani MN, Talabi, AO et al (2014) Delineation of groundwater potential zones in the crystalline basement terrain of SW Nigeria: an integrated GIS and remote sensing approach. Appl Water Sci4, 19-38. https://doi.org/10.1007/s13201-013-0127-9

Freeze RA, Cherry JA (1979) Groundwater. Prentice-Hall Inc., Englewood Cliffs, Vol. 7632 , 604.

Hencher SR, Lee SG, Carter TG. et al (2011) Sheeting Joints: Characterisation, Shear Strength and engineering. Rock Mech Rock Eng44, 1-22. https://doi.org/10.1007/s00603-010-0100-y

Hiscock K (2005) Hydrogeological Principles and Practice. Malden, Oxford, Carlton. Xvi+389. ISBN 0632057637.

Jayeoba A Oladunjoye MA (2013) Hydro-geophysical evaluation of groundwater potential in hard rock terrain of southwestern Nigeria. RMZ Mater Geo-environ 60:271-284

Jones HA, Hockey RD (1964) The Geology of Part of Southwestern Nigeria Geol. S Surv. Nigeria, Bull, 31, 101 p.

Kothari,CR (2004) Research methodology: Methods and techniques (2nd Ed.), New Delhi: New Age International Publishers.

Lewis MA (1987) The analysis of Borehole yields from Basement Aquifers. Proceedings of the Basement Aquifer Workshop,15-24 June, 1987, Zimbabwe, Common wealth Sciene Council CSC (89) WMR - 13, TP 273.

Lohman SW (1972) Groundwater Hydraulics. Professional Paper 708. https:// doi.org/ $10.313 / \mathrm{pp} 708$

Mogaji KA, Ezekiel GI, Abodunde OO (2021) Modelling of aquifer potentiality using GISBased knowledge-driven technique; a case study of hard rock geological setting, 
southwestern Nigeria, sustainable water Resources Management (2021) 7:64. https://doi.org/10.1007/s40899-021-00538-4

Mogaji KA, Lim HS (2020) A GIS-based linear regression modeling approach to assess the impact of geologicrock types on groundwater recharge and its hydrological implication Model. Earth Syst. Environ ISSN 2363-6203 Volume 6 Number 1. (2020) 6:183-199 DOI 10.1007/s40808-019-00670-3

Mogaji KA, Lim HS (2017) Development of groundwater favourability map using GISbased driven data mining models: an approach for effective groundwater resourcemanagement. GeocartoInternational. doi:10.1080/10106049.2016.1273 400.

Mogaji KA, Lim HS (2016) Groundwater potentiality mapping using geoelectrical- $\quad$ based aquifer hydraulic parameters: A GIS-based multi-criteria decision analysis modeling approach. Terr. Atmos. Ocean. Sci. doi: 10.3319/TAO.2016.11.01.02. Moroof OO, Gabriel OA (2014) Geophysical and Hydrochemical Evaluation of Groundwater Potential and Character of Abeokuta Area,SouthwesternNigeria.Doi:10.5539/jgg.v6n3p162.

Ozdemir A (2011) Using a binary logistic regression method and GIS for evaluating and mapping the groundwater spring potential in the Sultan Mountains (Aksehir, Turkey). Journal of Hydrology, 405(1), 123-136. https://doi.org/10.1016/j.jhydrol.2011.05.015

Ogunbo JN (2019) Auto Partial Curve Matching, Geophysics, Vol.83, No. 2 (March - April 2018); P.F21-f28, 7figs. 10.1190/Geo2016-0631.1.

Okogbue CO, Omonona OV (2013) Groundwater potential of the Egbe-Mopa basement area, central Nigeria. Hydrol. Sci. J. 58 Potential Groundwater Recharge Sites Mapping in a Typical Basement Terrain: a GIS Methodology Approach Oluwaseun Franklin 
OlabodeJournal of Geovisualization and Spatial Analysis volume 3, Article number: 5 (2019)

Olayinka AI (1996) Non-uniqueness in the interpretation of bedrock resistivity from sounding curves and its hydrogeological implications, water Resour 7(1 \& 2):49-55

Olorunfemi MO, Fasuyi SA (1993) Aquifer types and the geoelectric/hydrogeologic characteristics of part of the central basement terrain of Nigeria (Niger State). J Afr Earth Sci 16(3):309-31

Olorunniwo MA, Olorunfemi MO (1987) Geophysical Investigations for Groundwater in Precambrian Terrains: a case study from Ikare, Southwestern Nigeria. Journal of African Earth Sciences, 6(6): 787 - 796

Omotola OO, Oladapo MI, Akintorinwa OJ (2020) Modeling assessment of groundwater vulnerability to contamination risk in a typical basement terrain case of vulnerability techniques application comparison study. Model Earth Syst Environ 6:1253-128

Pradhan B, Neshat A, Pirasteh S, Shafri H Z M (2013) Estimating Groundwater Vulnerability to Pollution Using a Modified DRASTIC Model in the Kerman Agricultural Area. Iran. Environ Earth Sci. doi:10.1007/s12665-013-2690-7

Rahaman MA (1976) Review of the Basement Geology of SW Nigeria in Geology of Nigeria. Elizabithan Publishing Company, Nigeria. pp. 41-58

Rahaman,MA(1988) Recent advances in the study of the Basement Complex of Nigeria.In:Oluyide,P.O.,Mbonu,W.C.,Ogezi,A.E.,Egbuniwe,I.G.,Ajibade,A.C.and Umeji, A.C.(eds.). Precambrian Geology of Nigeria, G.S.N., pp.11-41 
Raviraj A, Nimmi K, Balaji K (2017) Identification of Potential Groundwater Recharge Zones Using Remote Sensing and Geographical Information System in Amaravathy Basin. Journal of Remote Sensing and GIS DOI:10.4172/2469-4134.1000213

Rawal D, Vyas A, Rao S (2016) Application of GIS and Groundwater Modelling Techniques to Identify the Perched Aquifers to Demarcate Water Logging Conditions Sciences, Volume III-8, 2016 XXIII ISRS Congresss, 12-19 July 2016, Prague,Czech Republic

Saaty TL (1980) The analytic hierarchy process: planning, priority setting, resource allocation. McGrawHill, New York

Saaty TL, Vargas GL (1991) Prediction, projection and forecasting. Kluwer, Dordrecht

Shaban A, Khawlie M, Abdallah C (2006) Use of remote sensing and GIS to determine recharge potential zones: the case of Occidental Lebanon. Hydrogeol J 14(4):433-

Shishaye HA, Tait DR, Befus KM, Maher DT (2019) An integrated approach for aquifer characterization and groundwater productivity evaluation in the Lake Haramaya watershed, Ethios-pia. Hydrogeol J27(6) 1212136. https//doi.org/101007/1004 0019019567

Singh KP (2005). A First Attempt for Determination Of Relationships Between Geophysical Parameters and Yield of the Aquifers. Presented In $91^{\text {st }}$ Conference $\quad$ of ISC, 3-7 January Punjab University, Chandigarh, India Sedgwick, 2019. BMJ clinical research. DOI:10:1136/BMJ.g7327

Sunmin L, Yunjung H, Moung-Jin L (2019) Groundwater Potential Mapping Using Data Mining Models of Big Data Analysis in Goyang-si, South Korea 
Toto EA, Kerrouri C, Zouhri L, Basri El, Ibenbrahim A, et al (2008) Geoelectricalexploration for groundwater in Al Maha Forest, AinJouhra, Moroco. Hydrol $\quad$ Processes $\quad 22: 1675-$ 1686

Umar ND, Igwe O (2019) Geo-electric method applied to groundwater protection of a granular sandstone aquifer. Applied Water Science, 9(4), 112. https://doi.org/10.1007/s13201-019-0980-2

Vander V (2004) WinRESIST Version 1.0 Resistivity Depth Sounding Interpretation Software. Delf, the Netherland: ITC

Zhou Y, Li W (2011) A Review of Regional Groundwater Flow Modelling Geoscience.

Zohdy AAR, Eaton GP, Mabey DR (1974) Application of surface geophysics to groundwater investigations. US Geological Survey, Reston, USGS-TWRI, Book $\quad 2$, Chapter DI 
Figures

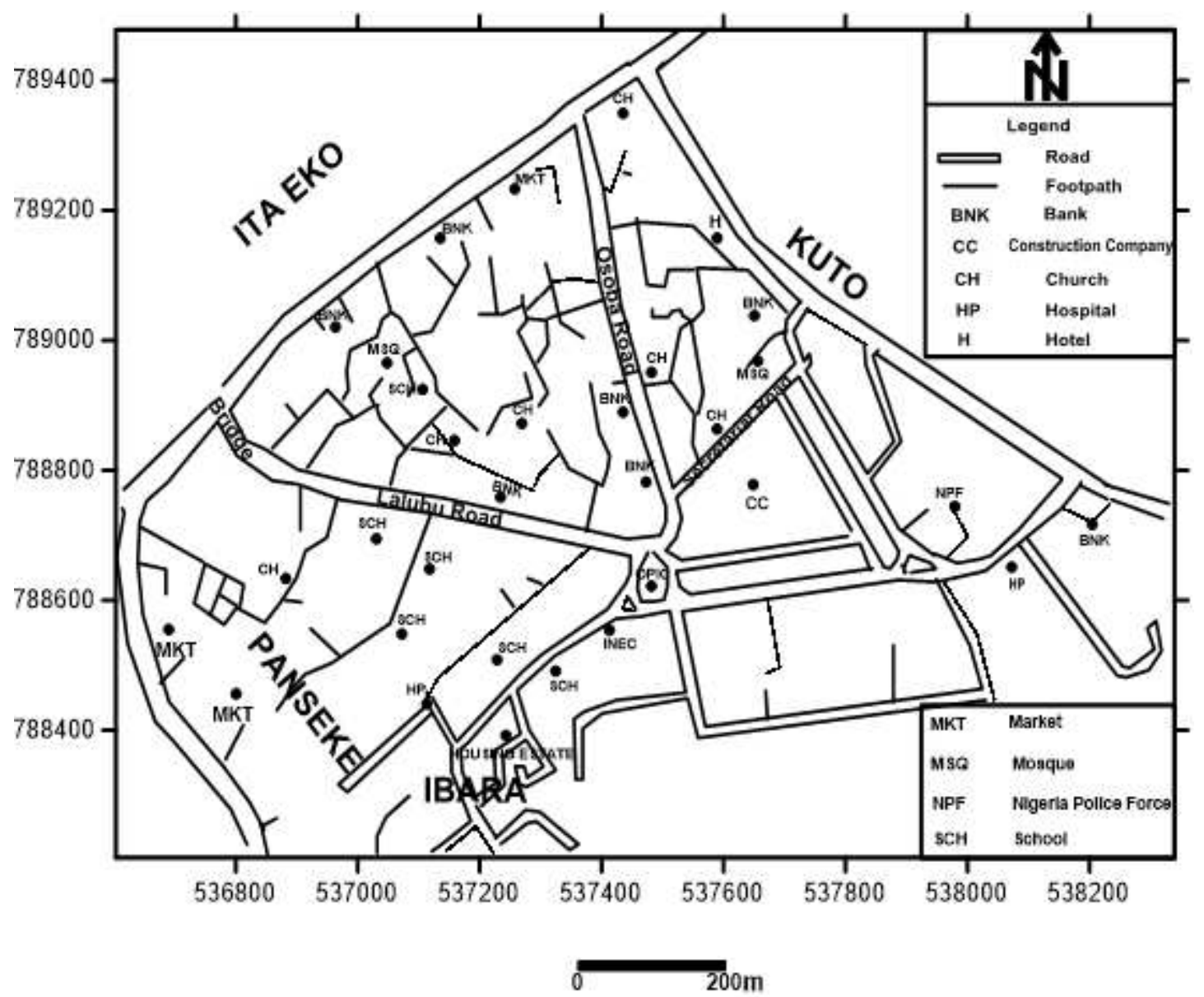

Figure 1

Base Map of the Study Area 


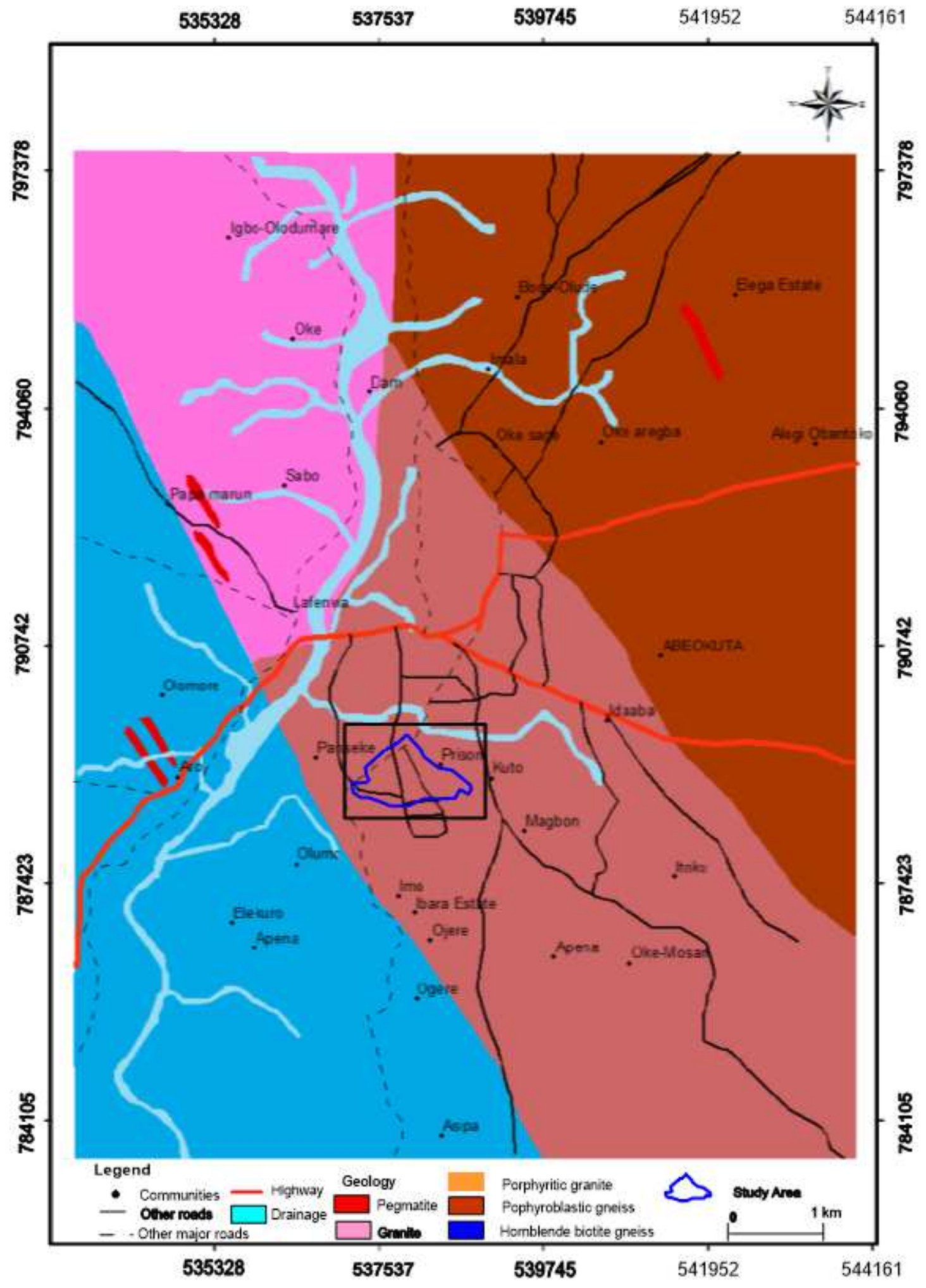

Figure 2

Geological map of Abeokuta (After Moroof and Gabriel, 2014) 


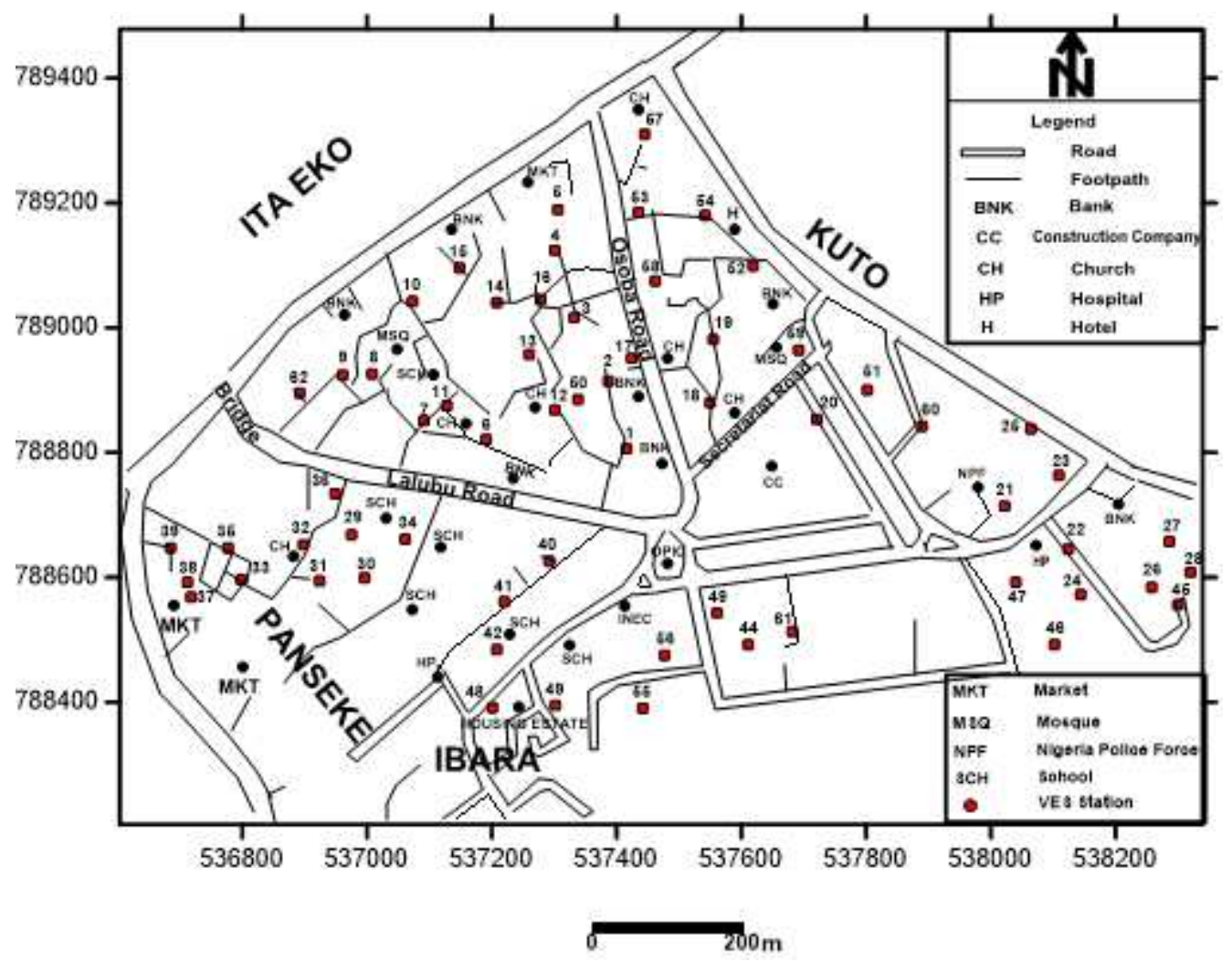

Figure 3

Data Acquisition Map of the Study Area Showing VES Station 


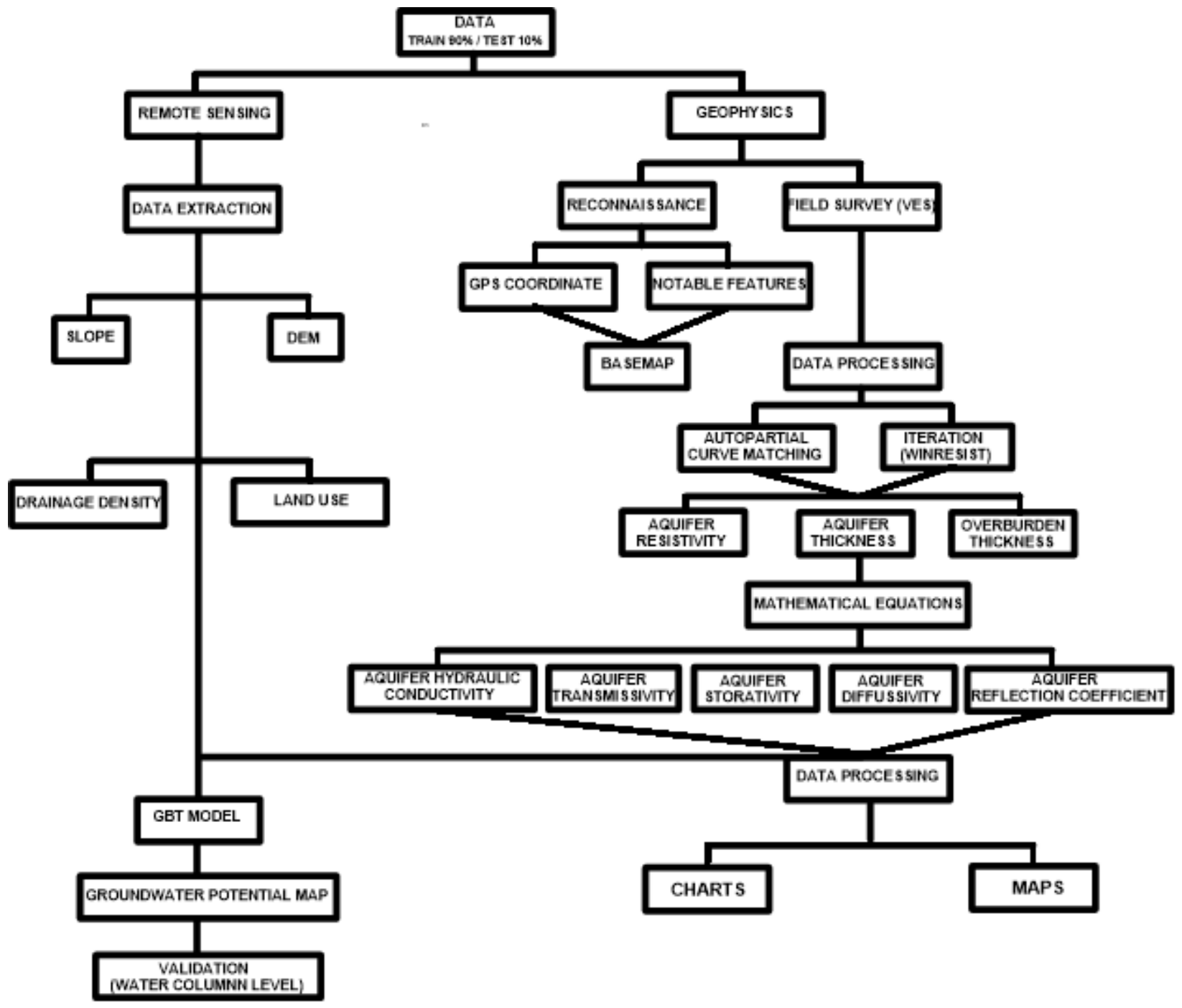

Figure 4

Methodology flow chart for groundwater potential evaluation 

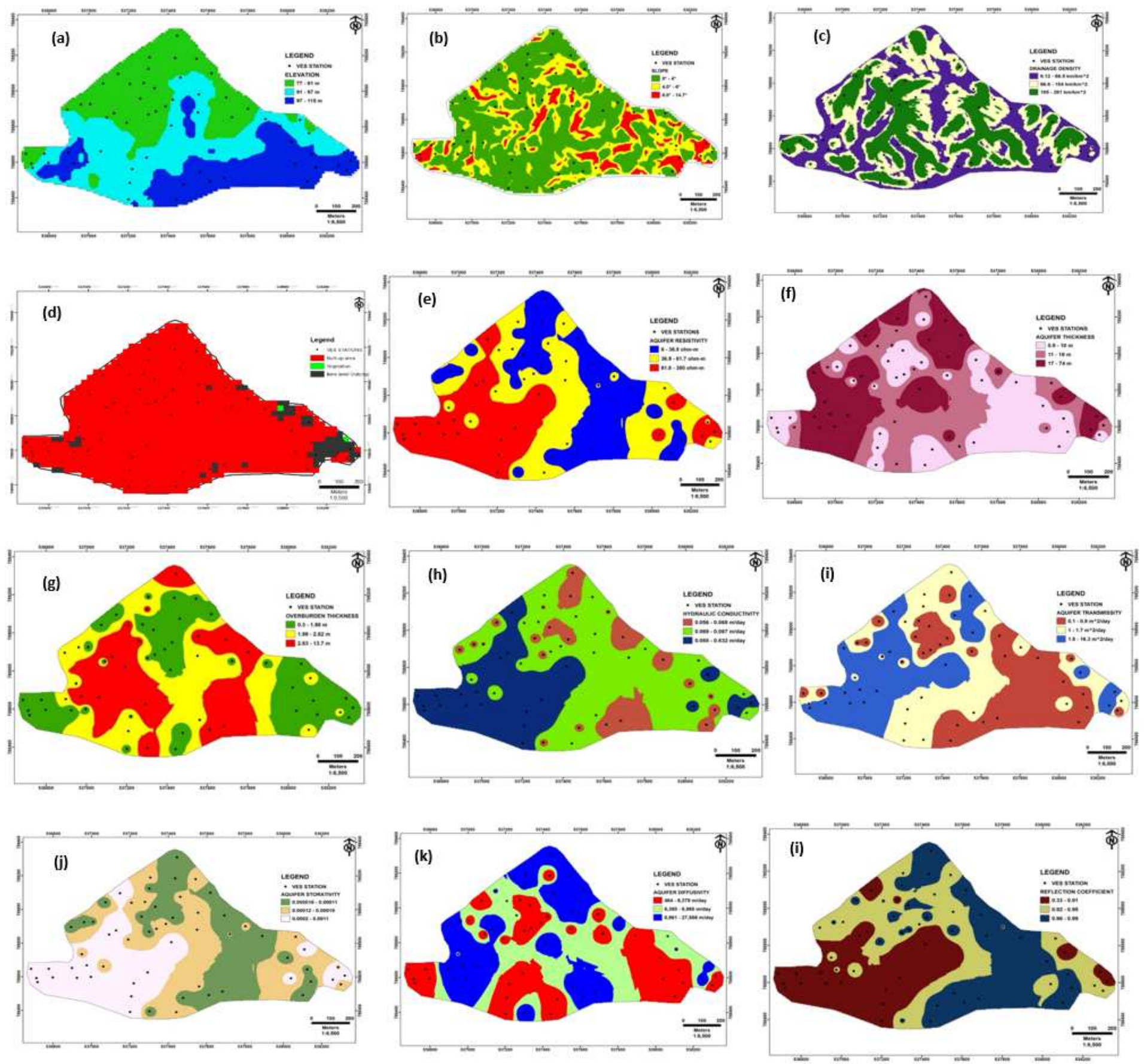

\section{Figure 5}

a - I: groundwater potentiality predictors (GPPs): a: Digital Elevation Model; map b: Slope map; c: Drainage density map; d: .Land use map; e: Aquifer resistivity map; f: Aquifer thickness map; g: Overburden thickness map; $\mathbf{h}$ : Aquifer hydraulic conductivity map; i: Aquifer transmissivity map; j: Aquifer storativity map; $\mathbf{k}$ : Aquifer diffusivity map; I: Aquifer reflection coefficient map 


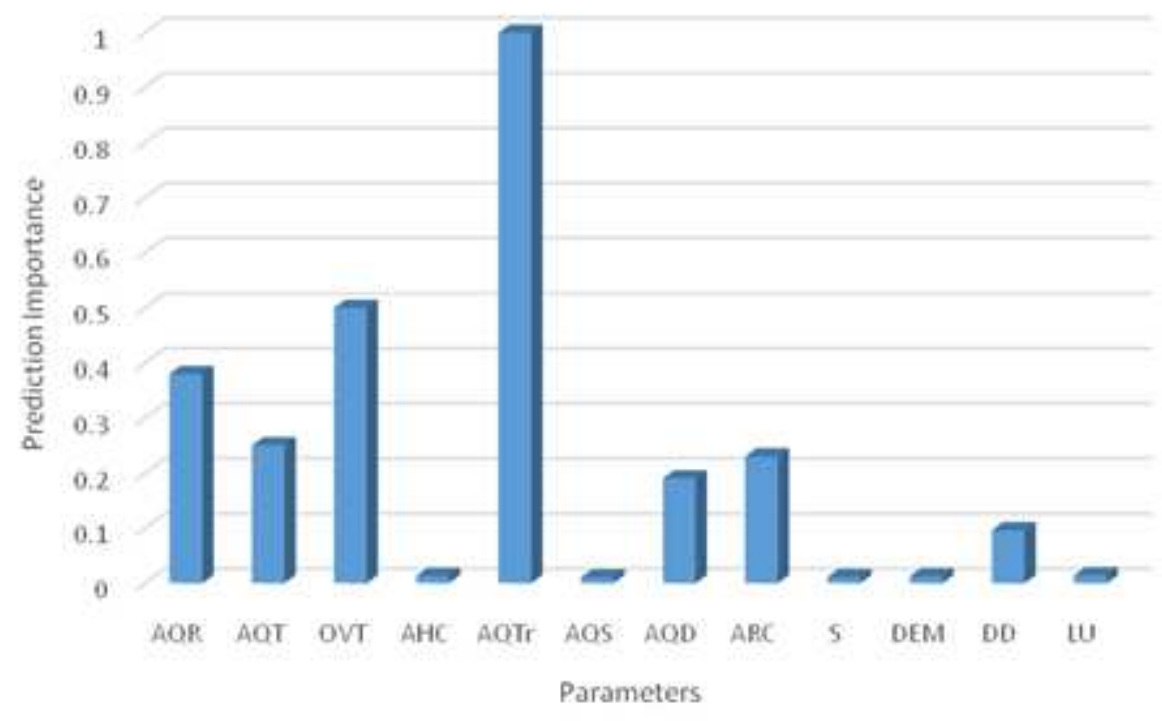

Figure 6

GBT model prediction importance rating
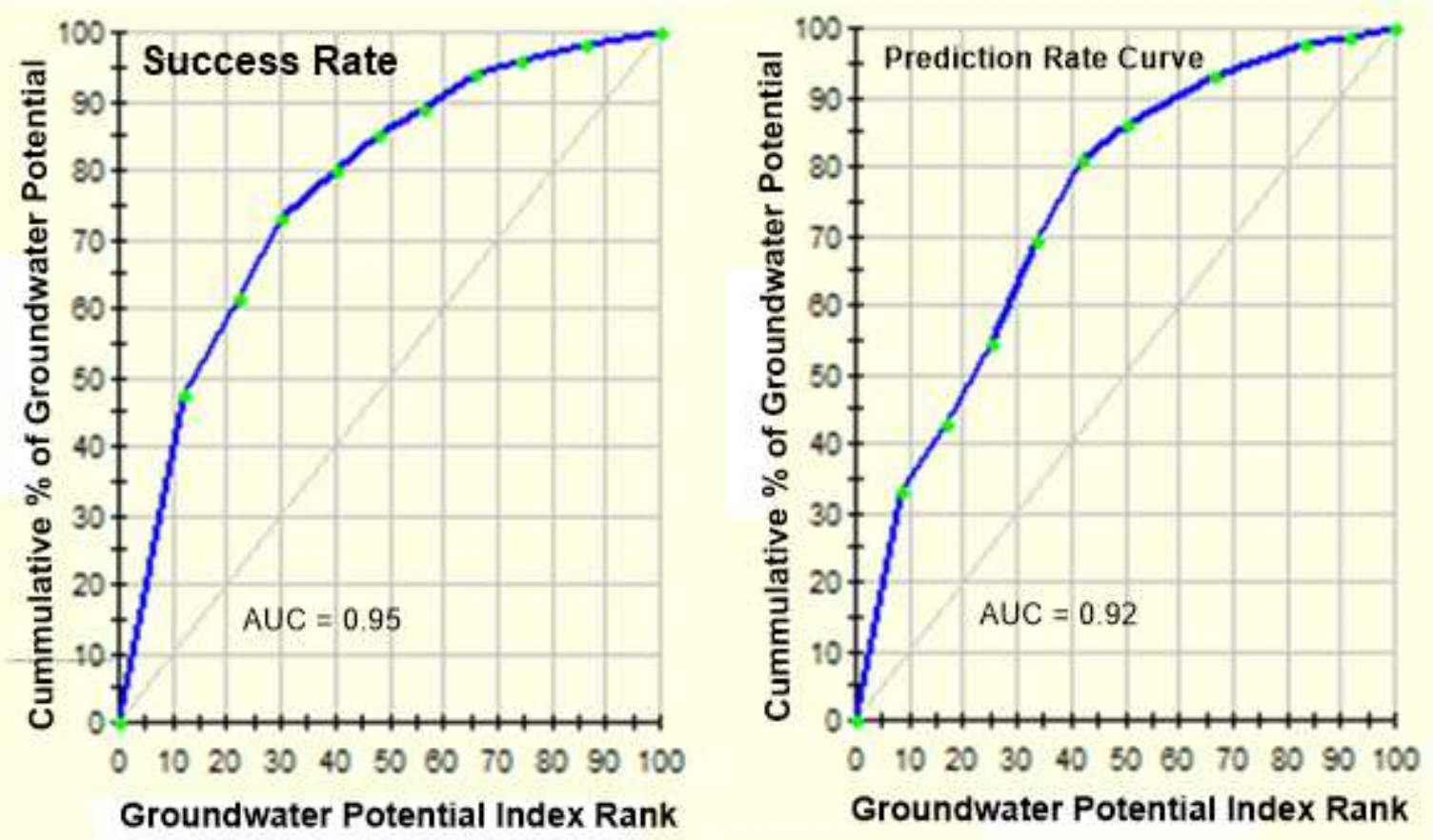

Figure 7

ROC graph plot showing the performances of the training and testing data 


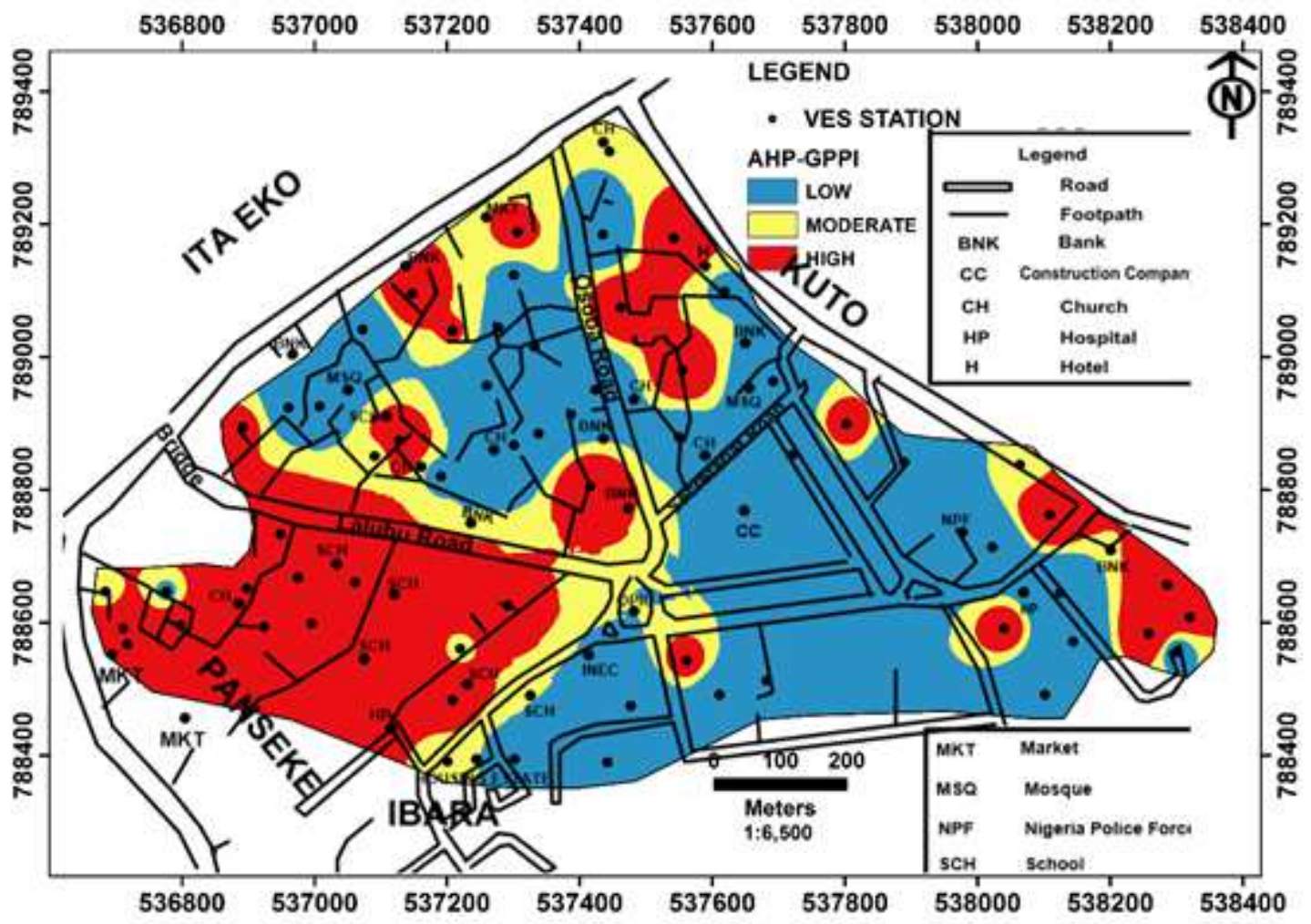

Figure 8

AHP-GPPI map of the study area 


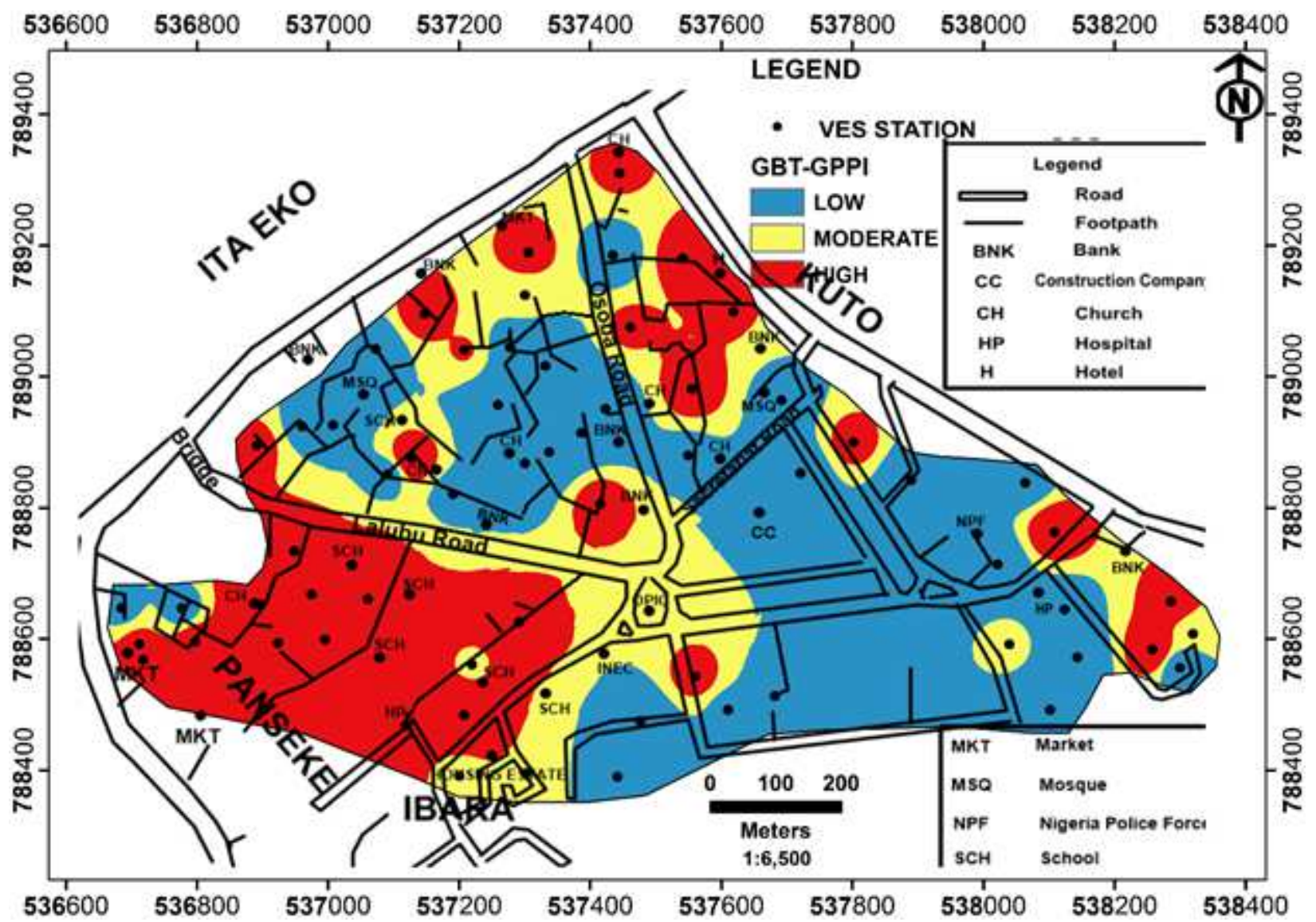

Figure 9

GBT-GPPI map of the study area 


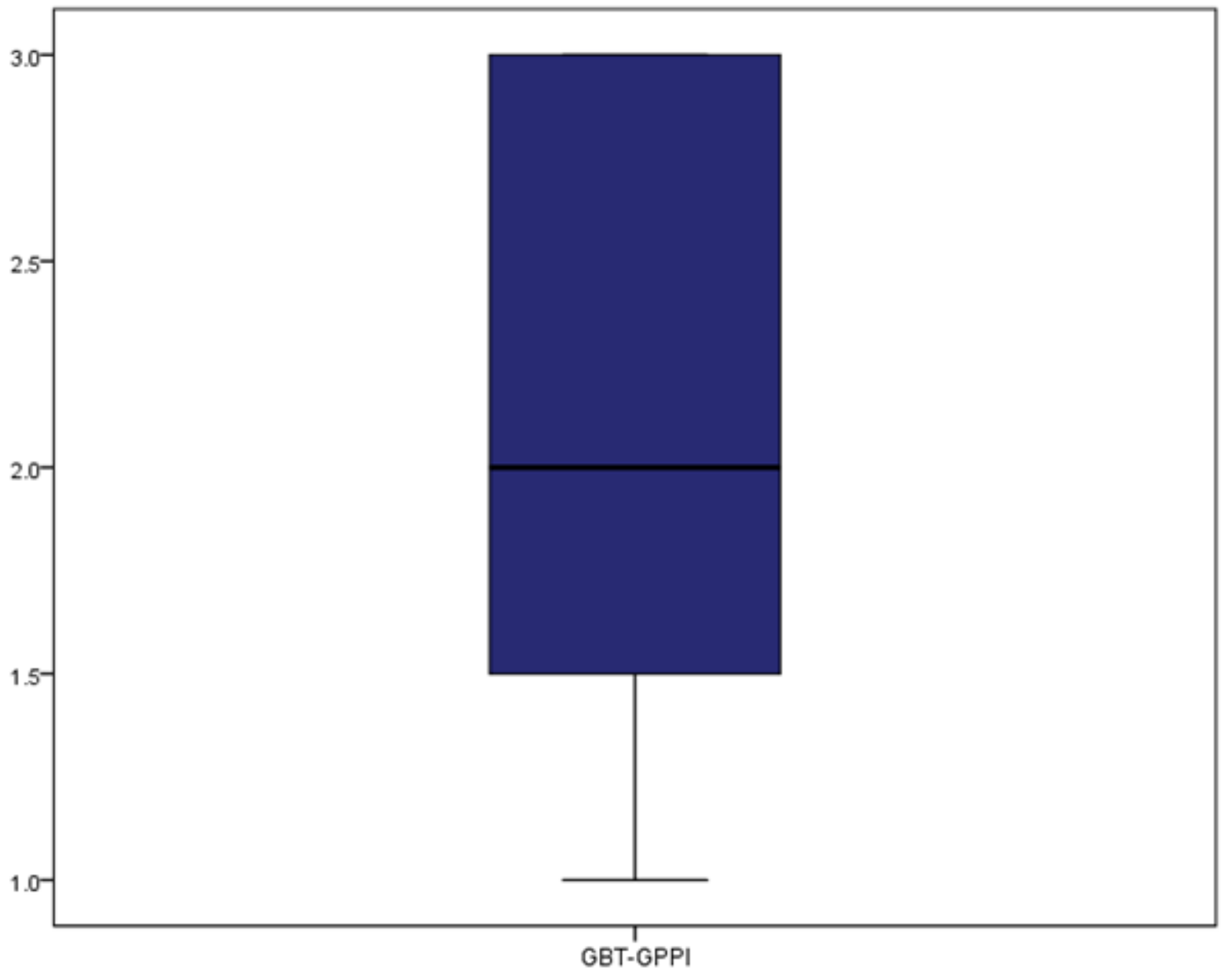

Figure 10

Box plot of non normally distributed data 


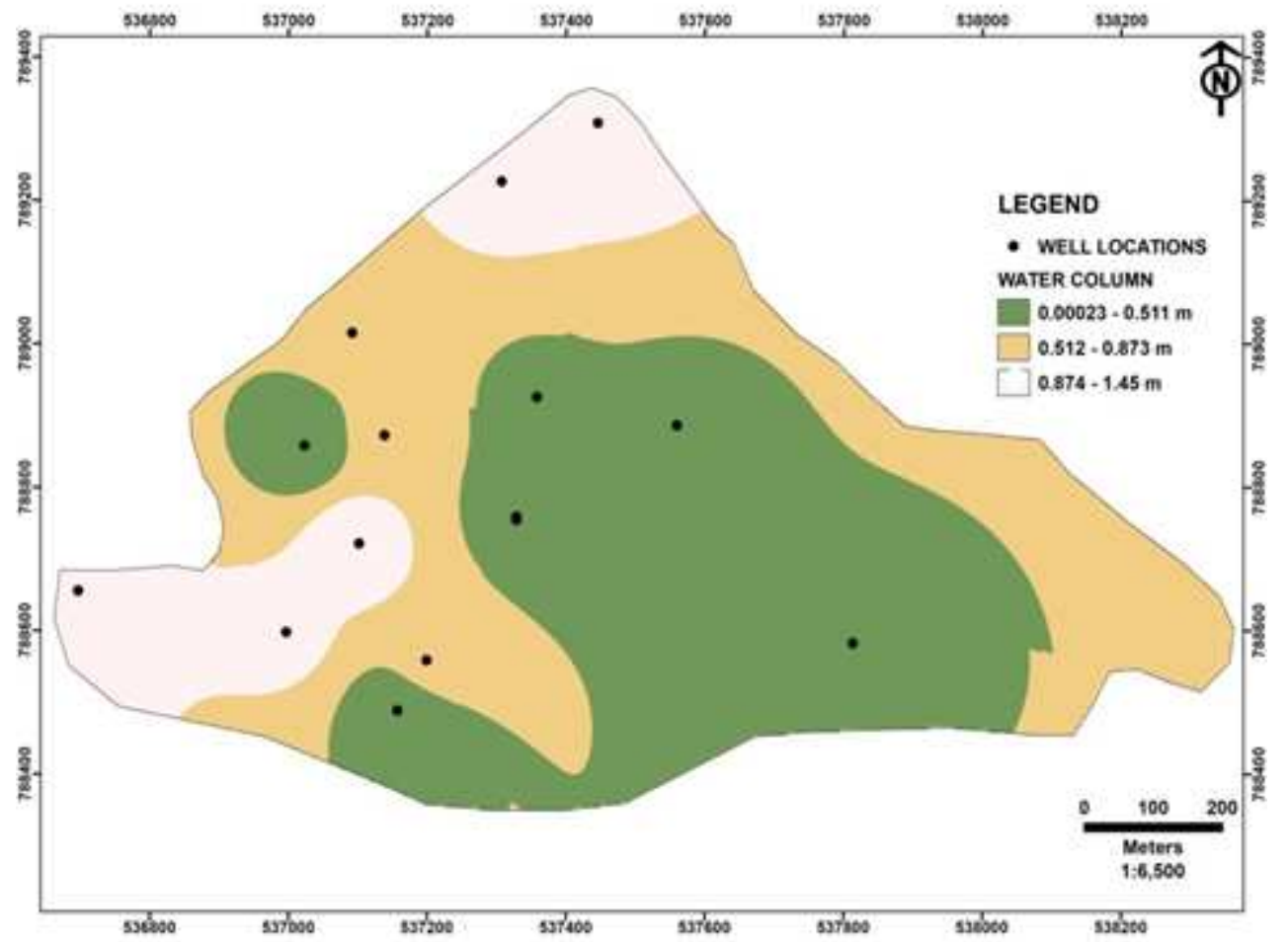

Figure 11

Water column validation map of the study area 